\title{
Prescripción de las multas formales y materiales. Constitucionalidad del Código Fiscal de la Provincia de Santa Fe
}

Formal and material fines' prescription. Province of Santa Fe's Tax Code Constitutionality

\author{
Ileana García Federici \\ Facultad de Ciencias Económicas \\ y Estadística, Universidad Nacional \\ de Rosario, Argentina. \\ E-mail: igfederici@fcecon.unr.edu.ar
}

Fecha de recepción: 01/10/2015 Fecha de aprobación: 01/12/2015

\section{Resumen}

Mediante la Nota Interna № 1/2015 la Administración Provincial de Impuestos de la Provincia de Santa Fe reconoce la naturaleza penal de los ilícitos tributarios tipificados en el Código Fiscal y la aplicabilidad en la especie de los principios generales del Derecho Penal.

En dicho reconocimiento, la Administración provincial realiza un giro de $180^{\circ}$ respecto de la posición que la Corte Suprema provincial y la Fiscalía de Estado venían sosteniendo en cuanto al carácter administrativo de las infracciones tributarias.

Tal reconocimiento suscitó como interrogante objeto de análisis en el presente trabajo: «al revestir los ilícitos tributarios naturaleza penal, icuál es la jurisdicción con potestad para legislar en materia de prescripción de sanciones por infracción a los deberes formales y materiales?».

A partir de la revisión de la jurisprudencia de la Corte Suprema de Justicia de la Nación, en cuanto a la distribución de facultades legislativas entre Nación y provincias emergente del texto constitucional, se

Palabras clave

- prescripción

- ilícitos tributarios

- naturaleza jurídica

- jurisdicción provincial

- constitucionalidad concluyó que es potestad excluyendo del Congreso Nacional el dictado de los Códigos de Fondo, entre ellos el Código Penal de la Nación, y consecuentemente legislar en materia de prescripción penal.

De ello se colige que los Códigos Fiscales provinciales, entre ellos el de Santa Fe, no pueden legislar en materia de prescripción de las infrac- 
ciones tributarias en contraposición con lo dispuesto en el Código Penal de la Nación, resultando cualquier disposición en contrario violatoria de nuestra Constitución Nacional.

Keywords

- prescription

- tax illicit

- legal nature

- provincial jurisdiction

- constitutionality

\section{Abstract}

By Internal Note No. 1/2015, the Administración Provincial de Impuestos of the Province of Santa Fe recognizes the criminal nature of tax illicit typified by the Tax Code, and the applicability to them of the general principles of criminal law.

In this recognition, the provincial administration makes a 180 degree turn from the position that the provincial Supreme Court and the Fiscalía de Estado had been sustaining as regards the administrative character of tax violations.

Such recognition arose the question analyzed in this paper: «having tax illicit a criminal nature, which jurisdiction has the power to legislate on the prescription of penalties for formal and material duty violations?».

From the review of the National Supreme Court of Justice jurisprudence, as regards the distribution of legislative powers between Nation and Provinces, which emerges from the Constitution, it can be concluded that it is exclusive authority of the National Congress to dictate the National Criminal Code, and therefore legislate on criminal prescription.

This indicates that provincial's Tax Codes, including Santa Fe's, cannot legislate on tax violations prescription in contrast with the provisions of the National Criminal Code, resulting any contrary disposition, a violation of our Constitution.

\section{Introducción}

A raíz de las recientes modificaciones introducidas al Título Séptimo — de las Infracciones y Sanciones - del Código Fiscal de Santa Fe por la Ley $N^{0} 13463$ comenzaron a regir en la provincia a partir del 01/03/2015, nuevos montos para las multas formales.

Esta modificación suscitó la inquietud respecto de si correspondía actualizar el importe de las multas por aquellas infracciones acaecidas con fecha anterior a la entrada en vigencia de la modificación, o bien si correspondía considerar el importe de multa vigente al momento en que se cometió la infracción.

Frente a esta encrucijada, la Administración Provincial de Impuesto mediante Nota $N^{\circ} 1 / 2015$ de fecha 10/06/2015, interpretó que:

Las resoluciones rigen para los contribuyentes a partir de su vigencia, como también rigen los montos fijados en la misma. En consecuencia, en materia de aplicación de sanciones a la infracción a los deberes formales, debe estarse a lo previsto en la normativa vigente al momento de la comisión del hecho sancionado. 